\title{
Application of Chitosan and Chinese Lemon Extract (Citrus Mitis) Based Edible Coating on Tuna Fillet
}

\author{
Nini Munirah Renur ${ }^{1}$, Yadi Haryadi ${ }^{2}$, Emmy Darmawati ${ }^{3}$, Imanuel Berly Delvis Kapelle ${ }^{4}$ \\ ${ }^{1}$ Fishery Product Technology, Polytechnic State Fisheries Tual, Maluku Southeast, Indonesia \\ ${ }^{2}$ Food Science Department, Agriculture Technology Faculty, Bogor Agricultural Institute, Bogor, Indonesia \\ ${ }^{3}$ Post-Hervest Technology Department, Agriculture Technology Faculty, Bogor Agricultural Institute, Bogor, Indonesia \\ ${ }^{4}$ Chemistry Department, Mathematic and Natural Science Faculty, Pattimura University, Maluku, Indonesia \\ Email address: \\ berly_mollucas@yahoo.com (I. B. D. Kapelle)
}

\section{To cite this article:}

Nini Munirah Renur, Yadi Haryadi, Emmy Darmawati, Imanuel Berly Delvis Kapelle. Application of Chitosan and Chinese Lemon Extract (Citrus Mitis) Based Edible Coating on Tuna Fillet. Journal of Food and Nutrition Sciences. Vol. 4, No. 2, 2016, pp. $29-33$.

doi: $10.11648 /$ j.jfns.20160402.11

\begin{abstract}
Fish is a food that is very susceptible to degradation. One way to maintain the freshness of the fish is by using packaging edible coating with natural ingredients. This study used that chitosan and chienese lemon extract (Citrus mitis) as the natural agent in edible coating production. The purpose of this study was to examine the application of edible coating made from chitosan and citrus mitis on tuna fillets and to test the application of edible coating at each concentration, to get the best concentration based on $\mathrm{pH}$ and Total Bacterial Count (TBC). Tuna fillet with a size of $3 \times 5 \mathrm{~cm}$ with a thickness of $1 \mathrm{~cm}$ was made edible coating by immersion system. Furthermore, edible coating made from chitosan in the concentrations of $1-4 \%$ was made by acetic acid solvent of $1 \%$ at a temperature of $50^{\circ} \mathrm{C}$ for $60 \mathrm{~min}$, followed by the addition of $0.5 \%$ glycerol. On the other hand, edible coating made from citrus mitis in the concentration of $10-40 \%$ was made by jelly solution of $1 \%$ at $50{ }^{\circ} \mathrm{C}$ for 60 min, followed by adding $0.5 \%$ of glycerol. Based on this study, it was understood that the best concentration for edible coating made from chitosan and citrus mitis was respectively $1 \%(\mathrm{pH} \mathrm{5.67}$; TBC 4.93) and 40\% (pH 5.32; TBC 6.23). Furthermore it was known that the higher acid concentration, the better edible coating was obtained.
\end{abstract}

Keywords: Edible Coating, Chitosan, Chienese Lemon Extract

\section{Introduction}

Efforts to maintain the level of freshness of the fish is very important. Fish is a food group that is very prone to degradation of quality. The quality of the fish quick setback took place after the fish die due to several factors, among others, the enzymatic process, or the presence of spoilage microorganisms that develop in the body of the fish. Biochemical changes and microbial postharvest in fish tissue is highly dependent significantly on factors that control the concentration of substrate and metabolites associated with microbial contamination and the condition after the arrest [1]. Good fresh fish handling needs to be done to maintain the level of freshness of the fish and extend shelf life.

The main role of packaging in the food industry is to preserve and protect the product from external contamination, including food safety, maintain quality and improve shelf life. To meet consumer demands for better food safety, much current research focuses on using natural ingredients to improve food quality and shelf life to avoid the use of synthetic preservatives [2]. Edible films and coatings is biodegradable materials offer an alternative packaging system that may replace some packaging materials synthesis or reduce the use of synthetic materials [3].

An Edible films and coatings are generally defined as a thin layer of edible material, formed in foods as a coating or placed on or between food components. The film can be applied by means of immersion, spraying and pouring [3]. Edible films and coatings are intended to help maintain the quality and shelf life of food products by controlling the transfer of moisture, oxygen, carbon dioxide, lipid, aroma, flavor, and food additives [4].

Chitosan is a natural polymer the second most abundant in nature after cellulose [5]. Because it is non-toxic, antibacterial, antioxidant, film-forming, biocompatibility and 
biodegradability, chitosan has attracted attention as a natural additive. In addition, chitosan also have the potential to be applied to the packaging of food, especially in edible films and coatings [6].

One of the natural ingredients that are safe to use to extend the freshness of the fish is chienese lemon (Citrus mitis) in Maluku, usually known as chienese lemon while in Manado known as lemon or orange cui musk. Lemon is typically used to remove the fishy smell and adds distinctive flavor to the fish. Chienese lemon contains elements of organic chemical compounds that are useful, for example: citric acid, formic acid, ascorbic acid (vitamin C) bioflavonoid, saponin, and linalin acetate. The natural component may cure coughs, smoothing the skin, reduce fever, and eliminate the fishy smell of fish and various types of seafood. Besides chienese lemon also contains a variety of minerals that are good for the health of the body, such as calcium and potassium in the form of potassium citrate and potassium oxalate [7].

The aim of this study was to look at the application of edible coating made from chitosan and chienese lemon extracts on tuna fillets. Creating and testing each concentration edible coating made from chitosan and chienese lemon extracts in order to obtain the best concentration in the review of the value of $\mathrm{pH}$ and Total Bacterial Count (TBC).

\section{Material and Methods}

\subsection{Materials}

The materials used in this study are chitosan, lemon china and tuna. Acetic acid 1\%, agar, aquades, plastic containers and styrofoam. The tool used for this study, among others, for the manufacture of edible coating is digital scales and hot plate magnetic stir. The tool used in the analysis of TB is test tubes, petri dishes, pipettes volumetric, incubators, vortex and digital colonicounter. The tools used to determine the $\mathrm{pH}$ value is a blender and a $\mathrm{pH}$ meter.

\subsection{Ways of Working}

The research was conducted in two (2) phases, namely: First; power study of antimicrobial edible coating made from chitosan on tuna fillets. Second; power study of antimicrobial edible coating made from chienese lemon extracts on tuna fillets.

\subsubsection{Power Study of Antimicrobial Edible Chitosan Coating Based on Fillet Skipjack}

Making the Edible Coating Solution.

The procedures for making a solution of edible coating of chitosan in this study using the method of [8] were modified. First chitosan is weighed according to the treatment concentration of 1, 2, 3 and 4\%. Then dissolved with a $1 \%$ solution of acetic acid by using a hot plate and magnetic stirr heating assistance at a temperature of $50^{\circ} \mathrm{C}$ for 60 minutes until a homogeneous solution and condensed. Then glycerol with a concentration of $0.5 \%(\mathrm{v}$ / v) was added little by little to a solution of edible coating, stirring constantly until a homogeneous for 5 to 10 minutes. Fillet of tuna in slices with a size of $3 \times 5 \mathrm{~cm}$ with a thickness of $1 \mathrm{~cm}$, then dipped in a solution with a concentration of chitosan according to treatment: 1, 2, 3 and $4 \%$. Long immersion is 2 minutes and then drained. Before testing the microbial activity, tuna fillets are kept for 24 hours at room temperature. $\mathrm{pH}$ is measured each treatment.

Microbial Activity Test Total Bacterial Count (TBC) [9].

The working principle of the analysis of total bacterial count (TBC) is a calculation of the number of colonies of bacteria present in the sample (fish meat) with dilution as needed and done triplo. The sample solution is prepared by mixing 10 grams of sample in $90 \mathrm{ml}$ of solvent. Dilution is done by taking a $1 \mathrm{ml}$ sample has been homogenized with a sterile pipette and put into a test tube containing a solution that has as many as $9 \mathrm{ml}$ sterile diluent to form a dilution of $10^{-1}$, after it was shaken so homogeneous. The amount of dilution carried out in accordance with the purposes of the study, a sample is usually diluted to $10^{-5}$ dilution. Pipetting is done of each tube retailing as much as $1 \mathrm{ml}$ sample and transferred into a sterile cup triplo with a sterile pipette. Media agar (Sodium Agar) is inserted into a petri dish of $10 \mathrm{ml}$ and shaken until the surface is so uneven (pour plate method), set aside a few moments to cool and harden. Petri dish containing agar and the sample solution inserted into incubator with an inverted position. Temperature incubator used is $\pm 30^{\circ} \mathrm{C}$ and incubated for 2 days, then was observed by counting the number of colonies in the petri dish.

Triplo observations conducted aseptically to prevent unwanted contamination. The number of bacterial colonies that can be counted is a petri dish of bacteria colonies that have between 30-300 colonies. In determining the Standard Plate Count (SPC), if the quotient between the number of bacterial colonies on dilution large (elected) by the number of colonies on dilution small (elected) smaller or equal to 2 , the value of SPC obtained by averaging the number of bacterial colonies from The second dilution. If the quotient is greater than 2, the value of SPC obtained by selecting the smallest number of bacteria coloni between two dilutions.

\subsubsection{Power Study of Antimicrobial Edible Coating Made Chienese Lemon Extract on Fillet Skipjack \\ Making the Edible Coating Solution.}

The procedures for making edible coating solution of chienese lemon extract that is first weighted according to the treatment concentration of $10,20,30$ and $40 \%$. Then dissolved with a solution so that $1 \%$ by using a hot plate and magnetic stir heating assistance at a temperature of $50^{\circ} \mathrm{C}$ for 60 minutes until a homogeneous solution and condensed. Then glycerol with a concentration of $0.5 \%(\mathrm{v} / \mathrm{v})$ was added little by little to a solution of edible coating, stirring constantly until a homogeneous for 5 to 10 minutes. Fillet of 
tuna in slices with a size of $3 \times 5 \mathrm{~cm}$ with a thickness of 1 $\mathrm{cm}$, then dipped in a solution of lemon extract with a concentration corresponding Chinese treatment that: 10, 20, 30 and $40 \%$. Long immersion is 2 minutes and then drained. Before testing the microbial activity, tuna fillets are kept for 24 hours at room temperature and then measuring the $\mathrm{pH}$ of each treatment.

Microbial Activity Test (Total Bacterial Count) [9].

The working principle of the analysis is the calculation of the number of colonies of TB bacteria in the sample (fish meat) with dilution as needed and done triplo. The sample solution is prepared by mixing 10 grams of sample in $90 \mathrm{ml}$ of solvent. Dilution is done by taking a $1 \mathrm{ml}$ sample has been homogenized with a sterile pipette and put into a test tube containing a solution that has as much as $9 \mathrm{ml}$ of sterile diluent to form a dilution of $10^{-1}$, after it was shaken so homogeneous. The amount of dilution carried out in accordance with the purposes of the study, a sample is usually diluted to $10^{-5}$ dilution. Pipetting is done of each tube retailing as much as $1 \mathrm{ml}$ of the sample solution and transferred into a sterile cup triplo with a sterile pipette. Media agar (sodium order) put in a petri dish of $10 \mathrm{ml}$ and shaken until the surface is so uneven (pour plate method), set aside a few moments to cool and harden. Petri dish containing agar and the sample solution inserted into incubator with an inverted position. Incubator used temperature is about $30^{\circ} \mathrm{C}$ and incubated for 2 days, then was observed by counting the number of colonies in the petri dish.

Triplo observations conducted aseptically to prevent unwanted contamination. The number of bacterial colonies that can be counted is a petri dish of bacteria colonies that have between 30-300 colonies. In determining the Standard Plate Count (SPC), if the quotient between the number of bacterial colonies on dilution large (elected) by the number of colonies on dilution small (elected) smaller or equal to 2, the value of SPC obtained by averaging the number of bacterial colonies from The second dilution. If the quotient is greater than 2, the value of SPC obtained by selecting the smallest number of bacterial colonies between two dilutions.

\section{Results and Discussion}

\subsection{Power Study of Antimicrobial Edible Coating Made from Chitosan on Tuna Fillets}

Testing $\mathrm{pH}$ value.

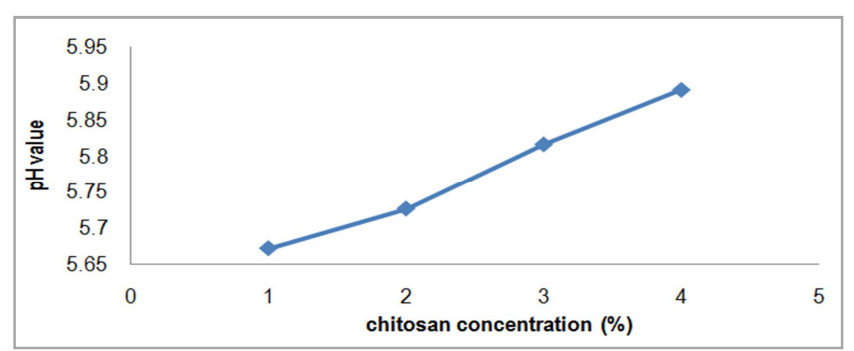

Figure 1. The relationship between the $p H$ value of the chitosan concentration.
$\mathrm{PH}$ value greatly affects the types of microorganisms that can grow. In general, microorganisms can grow in a $\mathrm{pH}$ range 3 - 6. Foods that have a low $\mathrm{pH}$ (below 4.5) are relatively more resilient during storage as compared to having a neutral or near-neutral $\mathrm{pH}$. During storage the numbers of bacteria increased. Factors that promote bacterial growth include: the availability of moisture content of materials, nutrients, oxygen, and oxidation-reduction potential, appropriate $\mathrm{pH}$, and the absence of substances that are toxic [10].

The results showed that the $\mathrm{pH}$ value obtained is directly proportional to the concentration of chitosan. The higher the concentration of chitosan on tuna fillet then the value will be close to neutral $\mathrm{pH}$. Edible coatings are made of chitosan using acetic acid as the solvent, so that with increasing concentrations of chitosan, the nature of the acidity of the mixture to be reduced.

Calculation of Total Bacterial Count (TBC).

The antibacterial activity of chitosan is affected by several factors, namely: the source of chitosan, the monomer units constituting the chitosan, microbes tested, the degree of distillation chitosan, the $\mathrm{pH}$ of the growing medium, the presence of metal ions is free, and the environmental conditions (moisture, nutrients available to microbes) [11]. Chitosan and its derivatives are a natural antimicrobial potential because it is a product of the utilization of waste. Various studies have proven the ability of chitosan as an antimicrobial [12].

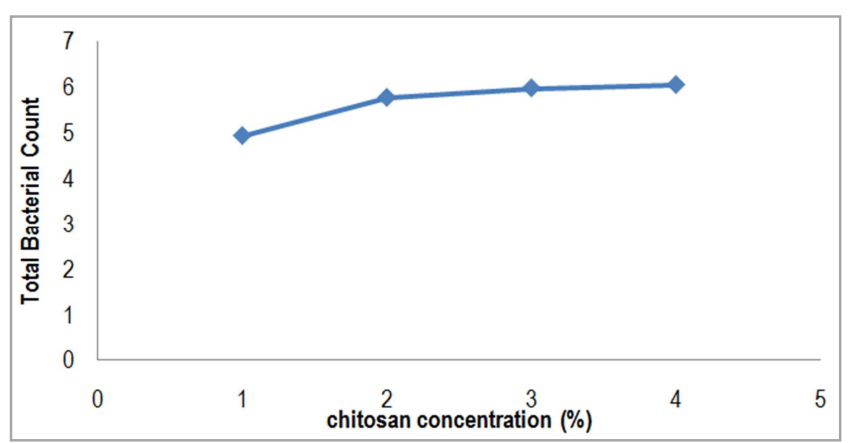

Figure 2. Relationship between the Total Bacterial Count (TBC) with a concentration of chitosan.

The graph above shows that the concentration of the best edible coating is chitosan $1 \%$ with a value of $4.93 \mathrm{log}$ tuberculosis $\mathrm{CPU} / \mathrm{ml}$. If connected to the $\mathrm{pH}$ value, the more acidic edible coating (small $\mathrm{pH}$ value), the better inhibit the growth of bacteria.

\subsection{Power Study of Antimicrobial Edible Coating Made from Chienese Lemon Extracts on Tuna Fillets}

\section{Testing $\mathrm{pH}$ value.}

The $\mathrm{pH}$ value is closely related to the protein structure of the meat and meat protein solubility resulting in further on the ability of meat to bind water and power emulsified meat protein. Emulsion products require a high $\mathrm{pH}$, which is above the isoelectric point of the protein that can bind water. $\mathrm{PH}$ values above the isoelectric point $(\mathrm{pH}>5.2-5.4)$ resulting proteins can 
bind hydrogen ions since the protein has a polar nature.

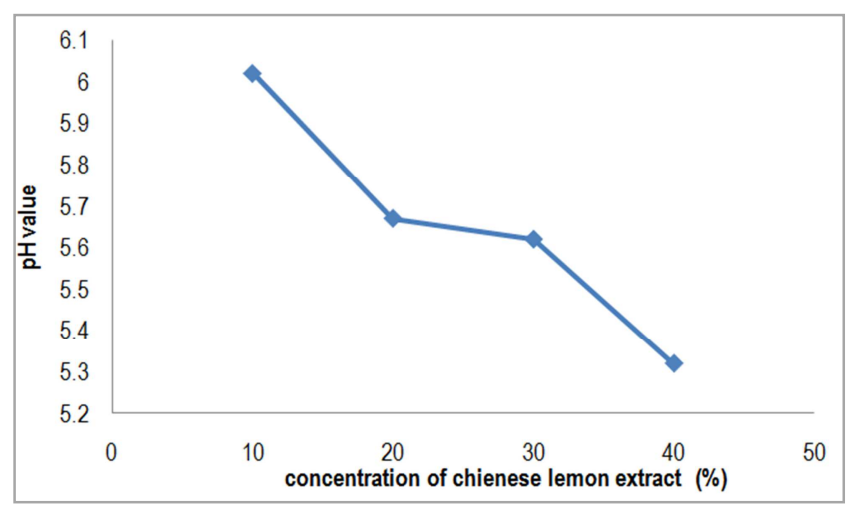

Figure 3. The relationship between the $\mathrm{pH}$ value of the concentration of chienese lemon extract.

Edible coating materials using lemon extract china as the base material. From the graph above it can be seen that the higher the concentration of chienese lemon extract used in the tuna fish fillet edible coating produced more acidic. Chienese lemon extract contains phenolic acids that cause the $\mathrm{pH}$ value of edible coating with a concentration of $40 \%$ lower.

\section{Calculation of Total Bacterial Count (TBC).}

On a previous study [13] the amount of the microbial population at the time of the formation of mucus is $3.0 \times 10^{6}$ to $3.0 \times 10^{8}$ colonies/gram sample and the amount of odor detected when the microbial population is $1.2 \times 10^{6}$ to $10^{8}$. The increase in the number of colonies on the clock to 24 suspected colonies that grow on the medium suspected of contamination or a less aseptic than treatment, in addition to the current TB testing begins dilution of high concentration (10-5), resulting in a large tuberculosis. Increasing the number of microorganisms is also supported by the storage duration. The number of colonies of products on the clock to 24 smaller compared to the control. The number of colonies on the control coatings have exceeded the ISO standard and visually has been damaged.

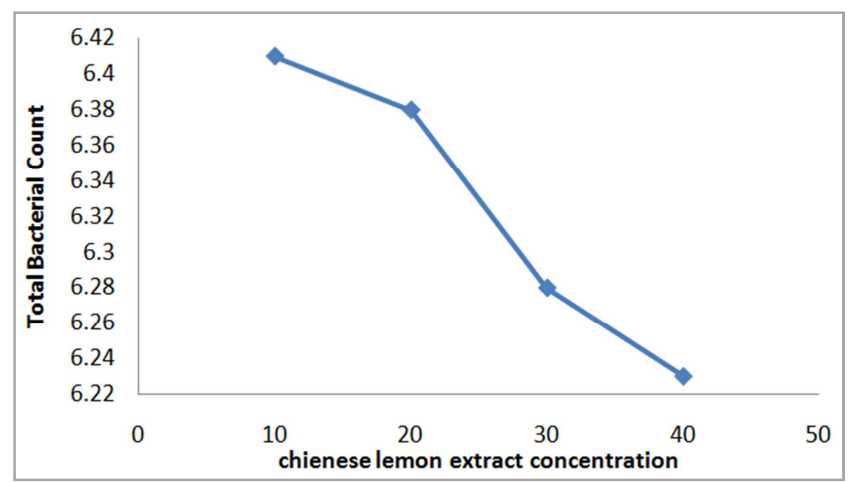

Figure 4. Relationship between the Total Bacterial Count (TBC) with chienese lemon extract concentration.

The graph above shows that the higher the concentration of chienese lemon extract on tuna fillet the better in inhibiting bacteria. Concentration is best in inhibiting bacteria is $40 \%$ the size of the $\log$ 6: $23 \mathrm{TBC} \mathrm{CPU} / \mathrm{ml}$. If connected with the existing $\mathrm{pH}$ value, the more acidic edible coating is used, the better the activity as an inhibitor of bacteria.

\section{Conclusion}

The conclusions that can be drawn from this study are: Edible coating made from chitosan which is best obtained at a concentration of $1 \%$ with a $\mathrm{pH}$ value $=5,671$ and Total Bacterial Count $(\mathrm{TBC})=4.93 \log \mathrm{CPU} / \mathrm{ml}$. Edible coatings made from the best chienese lemon extract obtained at a concentration of $40 \%$ to the value of $\mathrm{pH}=5.32$ and Total Bacterial Count $(\mathrm{TBC})=6.23 \log \mathrm{CPU} / \mathrm{ml}$. The higher the concentration of acid in the edible coating, the $\mathrm{pH}$ value and Total Bacterial Count (TBC) is getting lower and is excellent for inhibiting bacteria.

\section{References}

[1] Duran A, Erdemli U, Karakaya M, Yilmaz MT. 2008. Effects of slaughter methods on physical, biochemical and microbiological quality of rainbow trout Oncorhynchus mukiss and mirror carp Cyprinus carpio filleted in pre-, in- or post-rigor periods. Fish. Science. 1146-1156.

[2] Sathivel S. 2005. Chitosan and protein coatings Affect yield, moisture loss, and lipid oxidation of apple pink salmon fillets during frozen storage. Journal of Food Science 70: 445-459.

[3] Regalado C, Perez-Perez C, Lara Cortes E, Garcia Almendarez B. 2006. Whey protein based edible food packaging films and coatings. Agricultural and Food Biotechnology. pp. 237-261.

[4] Sothornvit R, Krotcha J M. 2005. Plasticizers in edible films and coatings. Innovation in Food Packaging. Pp. 403-433.

[5] Fan, W. J., Sun, J. X. \& Chen, Y. C. 2009. Effects of chitosan coating on quality and shelf life of silver carp during stogare frozen. Food chemistry, 115, 66-70.

[6] Casariego A, Souza BWS, Vicente AA, Teixeira JA, Cruz L, Diaz R. 2008. Chitosan coating surface properties as affected by plasticizer, surfactant and polymer concentrations in relation to the surface properties of chitosan coating. Food Hydrocolloids. 1452-1459.

[7] Soenaryono H. 1989. The introduction of species of fruit trees planting fruits in Indonesia. Sinar Baru. Bandung.

[8] Butler BL, Vergano PJ, testin RF, Bunn JM, JL Wiles. 1996. Mechanical and barrier properties of edible chitosan films as affected by composition and storage. J. Food Science. 953-955.

[9] Fardiaz S. 1987. Food Microbiology. Determination of Practice. Bogor: Department of Food Technology and Nutrition, Faculty of Agriculture T'eknologi, IPB.

[10] Fardiaz, S. 1992. Food microbiology I. PT. Gramedia Pustaka Utamaa, Jakarta.

[11] Thatte, MR 2004. Synthesis and antibacterial assessment of water-soluble chitosan derivatives bearing hydrophobic quarternary ammonium functionality [dissertation]. Los Angeles: Louisiana State University and Agricultural and Mechanical College. 
[12] Tsai, GJ Zhang, SL Shieh, PL 2004. Antimicrobial activity of the low molecular weight chitosan Obtained from cellulose digestion of chitosan. Journal of Food Prot 67: 396-398.
[13] Frazier WC and Westhoff DC. 1998. Food microbiology. Tata McGraw Hill Publ. Co. Ltd, New Delhi. 